\title{
Evaluasi In Vitro Kemampuan Penyerapan Glukosa oleh Ekstrak Daun Namnam (Cynometra cauliflora) pada Otot Diafragma Tikus
}

\section{Evaluation In Vitro Ability Of Glucose Uptake By Leaf Extract Namnam (Cynometra cauliflora) Diaphragm Muscle In Rats}

\author{
La Ode Sumarlin ${ }^{1}$, Agik Suprayogi ${ }^{2}$, Min Rahminiwati ${ }^{2}$, Aryani Satyaningtijas ${ }^{2}$ \\ Program Studi Kimia UIN Syarif Hidayatullah Jakarta \\ Jl Ir H Juanda No 9515419 Ciputat Tangerang Selatan Banten \\ ${ }^{2}$ Mayor Ilmu-ilmu Faal dan khasiat Obat, Sekolah Pascasarjana, IPB \\ Email:sumarlin@uinjkt.ac.id
}

Received: March 2018; Revised: May 2018; Accepted: May 2018; Available Online: May 2018

\begin{abstract}
Abstrak
Diabetes Melitus (DM) adalah kelompok gangguan metabolisme yang ditandai oleh hiperglikemia akibat kerusakan pada sekresi insulin, kerja insulin atau keduanya. Penderita Diabetes Melitus Tipe 2 (DMT2) mencapai $90-95 \%$ dari keseluruhan populasi penderita diabetes tersebut. Salah satu tanaman yang potensial sebagai alternatif obat antidiabetes adalah tanaman namnam (Cynometra cauliflora). Pada penelitian ini kemampuan penyerapan glukosa oleh otot diafragma yang diisolasi dari tikus non diabetes Sprague Dawley oleh ekstrak metanol daun namnam (C. cauliflora) pada berbagai konsentrasi ditentukan. Gugus fungsi senyawa dominan pada ekstrak menggunakan FTIR (Fourier Transform Infrared). Hasilnya menunjukkan bahwa terjadinya peningkatan penyerapan glukosa oleh diafragma ketika konsentrasi ekstrak daun namnam (C. cauliflora) meningkat dan tertinggi pada konsentrasi $450 \mathrm{mg} / \mathrm{mL}$ dengan serapan $0.4254 \pm 3.23 \mathrm{mg} / \mathrm{mL} / 30$ menit dengan peningkatan sebesar $373.72 \%$ dibandingkan kontrol air. Diduga kemampuan ekstrak tanaman C. Cauliflora menyerap glukosa disebabkan keberadaan golongan flavonoid. Oleh karena itu daun tanaman namnam (C. cauliflora) memiliki potensi sebagai obat antidiabetes DMT2 melalui mekanisme peningkatan penyerapan glukosa ke dalam sel.
\end{abstract}

Kata kunci: Diabetes melitus tipe 2, diafragma, penyerapan glukosa

\begin{abstract}
Diabetes Mellitus (DM) is a group of metabolic diseases characterized by hyperglycemia due to damage to insulin secretion, insulin work or both. Diabetes Mellitus Type 2 (DMT2) patients reach 90-95\% of the overall population of diabetics. One potential plant as an alternative to antidiabetic drugs is namnam plant (C. cauliflora). In this study, the ability of glucose uptake by diaphragm muscle isolated from non diabetic Sprague Dawley rat by namnam leaf methanol extract (Cynometra cauliflora) at various concentrations was determined. The functional groups of dominant compounds in the extract using FTIR (Fourier Transform Infrared). The results showed that the increase in glucose uptake by diaphragm was discovered when the concentration of namnam leaf extract (C. cauliflora) raised and reached the highest level at $450 \mathrm{mg} / \mathrm{mL}$ with glucose uptake to $0.4254 \pm 3.23 \mathrm{mg} / \mathrm{mL} / 30$ minute which increase of $373.72 \%$ compared to water control. Suspected of the ability of plant extract C. Cauliflora in glucose uptake caused by the presence of flavonoid groups. Therefore, the plant leaves namnam (C. cauliflora) had potential as an antidiabetic drug of DMT2 through the mechanism of increasing glucose uptake into the cells.
\end{abstract}

Keyword: Diabetes mellitus type 2, diaphragm, glucose uptake

DOI: http://dx.doi.org/10.15408/jkv.v4i1.7345 


\section{PENDAHULUAN}

Diabetes Melitus (DM) merupakan epidemi modern yang mempengaruhi 415 juta orang dewasa di seluruh dunia dan diperkirakan tahun 2040 akan mencapai 642 juta (IDF, 2015). Penelitian Riskesdas (2013) juga menunjukkan peningkatan penderita DM dari 1,1 persen (2007) menjadi 2,1 persen (2013). Jika melihat pola pertambahan penduduk saat ini, diperkirakan pula bahwa pada tahun 2030 penduduk yang menderita DM di Indonesia sebesar 21,3 juta. Salah satu kelompok Diabetes Melitus adalah Diabetes Melitus Tipe 2 (DMT2) yang mencapai 9095\% dari keseluruhan populasi penderita diabetes (Shaw et al., 2010). Di Indonesia DMT2 sekitar 12 juta yang berusia di atas 15 tahun (Riskesdas, 2013).

Kasus DMT2 pada umumnya mempunyai latar belakang resistensi insulin. Resistensi insulin akan menyebabkan kemampuan sel dalam menyerap glukosa ke dalam sel (misalnya sel otot) makin rendah, akibatnya glukosa darah meningkat. Hal ini terjadi karena sel otot merupakan salah satu jaringan target insulin yang berperan dalam mempertahankan homeostasis gula darah.

Dengan demikian dibutuhkan suatu upaya untuk mendapatkan agen hipoglikemik baru yang memiliki fungsi meningkatkan penyerapan glukosa pada otot. Salah satu bahan alam yang memiliki potensi sebagai agen hipoglikemik tersebut adalah daun namnam (Cynometra cauliflora).

Hasil uji fitokimia terhadap ekstrak daun namnam (C. cauliflora) menunjukkan bahwa ekstraksi maserasi (Metanol) dan caircair (n-butanol) menunjukkan adanya kandungan metabolit sekunder antara lain saponin, steroid atau triterpenoid, fenolik, flavonoid, tanin, dan kuinon (Sumarlin et al., 2016). Selain itu Ekstrak Metanol Daun Namnam (EMDN) juga mengandung $\beta$ karoten sebesar $1.013 \pm 0.020 \mathrm{mg} \beta \mathrm{CE} / \mathrm{g}$ (Capillary Electrophoresis) (Sumarlin et al., 2015a). Menurut Jung et al., (2006) sebagian besar tanaman yang mengandung glikosida, alkaloid, terpenoid, flavonoid, karotenoid dapat dikembangkan sebagai antidiabetes.

Oleh karena itu daun namnam (C. cauliflora) diduga memiliki potensi sebagai antihiperglikemia. Kemampuan penyerapan glukosa ini dapat diperkirakan melalui metode in vitro menggunakan sel diafragma tikus. Diharapkan penelitian ini memberikan informasi kemampuan ekstrak daun namnam ( $C$. cauliflora) menyerap glukosa ke dalam sel sebagai salah satu mekanisme agent antidiabetes DMT2.

\section{METODE PENELITIAN}

\section{Bahan dan Alat}

Alat yang digunakan dalam penelitian ini berupa alat-alat gelas, spektrofotometer UV-Vis, rotary evaporator, alat pengukur gula (Easy Touch ${ }^{\circledR}$ ), pipet mikro, kandang hewan (dan kelengkapannya), tabung gas, waterbath, peralatan bedah tikus, neraca analitik (OHAUS), FTIR (Fourier Transform Infrared) merk Shimadzu IRPrestige-21 holder ATR-8200 H dan alat penunjang lainnya.

Bahan uji yang digunakan dalam penelitian ini adalah daun namnam (C. cauliflora) yang diperoleh dari Desa Cintaratu, Kecamatan Parigi, Kabupaten Pangandaran, Jawa Barat tahun 2012 bulan Mei, pakan standar tikus, Kit Glukosa (Human), Human Insulin (NovoRapid®FlexPen®) $100 \mathrm{IU} / \mathrm{mL}$, serta bahan kimia pure analysis. Hewan percobaan yang digunakan tikus putih (Rattus norvegicus) galur Sprague Dawley jantan berusia 3.5-4 bulan dengan bobot badan 200250 gram g sebanyak 15 ekor (@ n=3)

\section{Preparasi dan Ekstraksi Sampel Daun Namnam}

Daun namnam (C. cauliflora.) dicuci dengan air mengalir, disortasi lalu dikeringkan dengan sinar matahari selama 30 jam sampai kadar air 9-10\%. Sampel daun namnam (C. cauliflora) yang telah kering, disortir dan selanjutnya dihancurkan dengan blender, sehingga diperoleh serbuk halus. Ukuran sampel yang kecil (serbuk halus) diharapkan dapat memperluas permukaan bahan yang kontak langsung dengan pelarut, sehingga proses ekstraksi komponen bioaktif dapat berjalan dengan maksimal.

Serbuk daun namnam ( $C$. cauliflora) sebanyak 100 gram direndam dalam $500 \mathrm{~mL}$ metanol p.a dan dilakukan maserasi selama 24 jam. Lalu disaring dengan kertas saring Whatman no.1, sehingga diperoleh filtrat yang pertama dan residu pertama. Kemudian residu pertama dimaserasi kembali (remaserasi) dengan metanol p.a sebanyak 250 
$\mathrm{mL}$ selama 9 jam, sehingga diperoleh filtrat yang kedua. Filtrat pertama dan filtrat kedua dicampur, lalu dipekatkan pada vakum rotary evaporator (suhu $45-50{ }^{\circ} \mathrm{C}$ ). Hasilnya berupa ekstrak kental yang dikenal sebagai ekstrak kasar (crude extract). Ekstrak kasar ini dibuat dalam konsentrasi $150 \mathrm{mg} / \mathrm{mL}, 300 \mathrm{mg} / \mathrm{mL}$ dan $450 \mathrm{mg} / \mathrm{mL}$ dan diuji kemampuan serapan glukosa pada otot diafragma tikus nondiabetes.

\section{Ekstraksi Cair-Cair}

Metode ekstraksi cair-cair dilakukan menggunakan corong pisah. Sebelum dipartisi, ekstrak kental metanol didispersikan dengan air hangat $\left( \pm 40{ }^{\circ} \mathrm{C}\right)$ terlebih dahulu untuk mempermudah kelarutannya, kemudian difraksinasi dengan n-butanol dan air hingga terbentuk 2 fase dan dipisahkan. Partisi dilakukan berulang hingga fase metanol yang berada di atas jernih yang menandakan bahwa senyawa metabolits sekunder dalam sampel telah terlarut seluruhnya ke dalam pelarut. Tiap fase yang diperoleh diuapkan dengan rotary evaporator vakum pada suhu $35^{\circ} \mathrm{C}$, kemudian dikeringkan kembali dalam oven pada suhu $35{ }^{\circ} \mathrm{C}$ hingga diperoleh residu untuk uji FTIR

\section{Metode sediaan diafragma tikus}

Metode sediaan diafragma tikus digunakan untuk meneliti pemakaian glukosa periferal. Larutan tirode dibuat dengan melarutkan $8 \mathrm{~g} \mathrm{NaCl} ; 0.2 \mathrm{~g} \mathrm{KCl} ; 0.2 \mathrm{~g} \mathrm{CaCl}_{2}$; $0.1 \mathrm{MgCl}_{2}$ dalam $250 \mathrm{~mL}$ ar suling sebagai larutan A dan $0.05 \mathrm{~g} \mathrm{NaH}_{2} \mathrm{PO}_{4} ; 1 \mathrm{~g} \mathrm{NaHCO}_{3}$ dalam $250 \mathrm{~mL}$ air suling sebagai larutan $\mathrm{B}$ serta $1 \mathrm{~g}$ glukosa dalam $500 \mathrm{~mL}$ air suling sebagai larutan C. Setelah itu, $250 \mathrm{~mL}$ larutan A dicampurkan dengan $250 \mathrm{~mL}$ larutan $\mathrm{B}$ dan $500 \mathrm{ml}$ larutan C. Tikus dengan bobot 150-
$200 \mathrm{~g}$, sehat dan non-diabetes dipelihara dengan ransum standar, air ad libitum. Lalu dipuasakan semalam sebelum diambil diafragmanya. Tikus dimatikan dengan cara dislocatio cervicalis dan diafragma diambil dengan cepat untuk mencegah trauma. Setelah itu, diafragma dicuci menggunakan larutan tirode tanpa glukosa. Sampel pada analisis ini berupa ekstrak daun namnam. Pengukuran penyerapan glukosa oleh sel diafragma pada sampel dilakukan dengan pengelompokkan berikut (Tabel 1).

Setelah larutan disiapkan, kemudian diafragma tikus dimasukkan ke dalam tabung reaksi dan diinkubasi (Gambar 1). Inkubasi dilakukan selama 30 menit dengan suhu $37{ }^{\circ} \mathrm{C}$ dengan penambahan $\mathrm{O}_{2} 95 \%$ dengan inkubator goyang $140 \mathrm{rpm}$. Setelah inkubasi, diafragma dibilas dengan air suling, kemudian dikeringkan bagian luarnya dan ditimbang dengan neraca analitik. Larutan tirode yang telah ditambahkan sampel atau insulin diukur kadar glukosanya sebelum dan sesudah inkubasi dengan diafragma. Penentuan kadar glukosa dilakukan dengan metode glukosa oksidase (GOD-PAP). Kadar glukosa yang telah diperoleh kemudian dibagi dengan bobot diafragma tiap tabung (Sabu dan Subburaju, 2002).

Perhitungan:

\section{Kadar glukosa yang terserap : $[(\mathbf{G 1}-\mathbf{G 2})] / \mathrm{W}$}

Keterangan:

G1:Kadar gukosa sampel/insulin sebelum inkubasi $(\mu \mathrm{g})$

G2:Kadarglukosa sampel/insulin sesudah inkubasi $(\mu \mathrm{g})$

W: Bobot diafragma (g)

Tabel 1. Pengelompokan dan perlakuan penyerapan glukosa oleh otot diafragma pada beberapa konsentrasi ekstrak metanol daun namnam

\begin{tabular}{ll}
\hline Kel & Perlakuan \\
\hline I & $2 \mathrm{~mL}$ Larutan tirode (mengandung glukosa) dan $2 \mathrm{~mL}$ akuades sebagai kontrol. \\
II & $2 \mathrm{~mL}$ larutan tirode (mengandung glukosa) dan $2 \mathrm{~mL}$ Insulin $(400 \mu \mathrm{L}$ Insulin regular $100 \mathrm{IU}$ \\
& dalam $100 \mathrm{~mL}$ ) sebagai pembanding positif. \\
III & $2 \mathrm{~mL}$ larutan tirode (mengandung glukosa) dan $2 \mathrm{~mL} \mathrm{EMDN} 150 \mathrm{mg} / \mathrm{mL}$ \\
IV & $2 \mathrm{~mL}$ larutan tirode (mengandung glukosa) dan $2 \mathrm{~mL} \mathrm{EMDN} 300 \mathrm{mg} / \mathrm{mL}$ \\
V & $2 \mathrm{~mL}$ larutan tirode (mengandung glukosa) dan $2 \mathrm{~mL} \mathrm{EMDN} 450 \mathrm{mg} / \mathrm{mL}$ \\
\hline Keterangan : EMDN : Ekstrak Metanol Daun Namnam
\end{tabular}




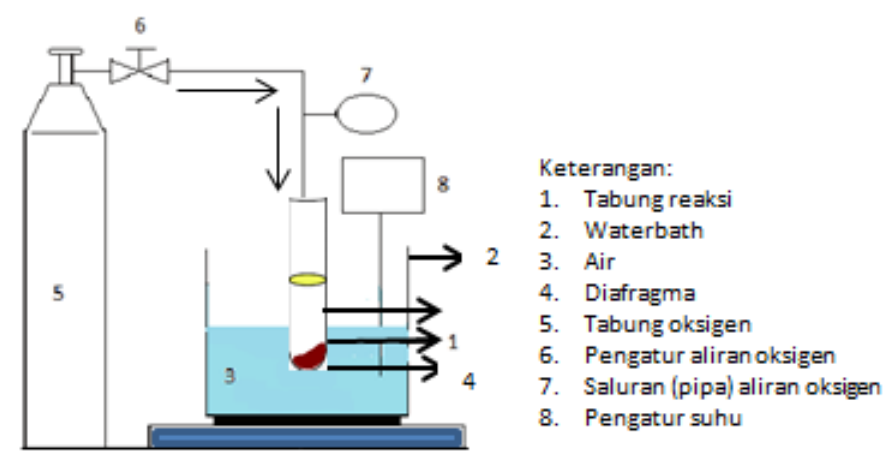

Gambar 1. Rangkaian peralatan pengukuran serapan glukosa oleh diafragma

\section{Analisis Gugus Fungsi Menggunakan FTIR}

Sampel EMDN sebanyak $1 \mathrm{mg}$ dicampurkan dengan $100 \mathrm{mg}$ serbuk $\mathrm{KBr}$ dengan lumpang agate atau vibrating ball mill hingga homogen. Setelah itu ditempatkan dalam sampel spektrofotometer FTIR. Kemudian direkam spektrumnya pada bilangan gelombang $4000-450 \mathrm{~cm}^{-1}$ dan dianalisa lebih lanjut.

\section{Analisis Data}

Data hasil pengukuran dianalisis menggunakan Software-SPSS 22,0. Data yang diperoleh diperlakukan sebagai data berkaitan dan dibuktikan dengan uji Anova satu arah. Untuk kelompok uji yang memiliki perbedaan bermakna dilanjutkan dengan uji Duncan. Batas kemaknaan yang digunakanadalah $\mathrm{p}<0.05$. Data sampel darah yang didapat diolah secara statistika dengan metode uji software SPSS untuk mengetahui perbedaan bermakna dari setiap kelompok pada $\mathrm{P}<0.05$ terhadap kelompok kontrol.

\section{HASIL DAN PEMBAHASAN}

Agen antidiabetes dapat mempengaruhi beberapa jalur metabolisme glukosa seperti sekresi insulin, serapan glukosa oleh organ sasaran, dan penyerapan nutrisi. Oleh karena itu, perhitungan kandungan glukosa dalam hemidiafragma tikus merupakan metode untuk menentukan efisiensi tanaman secara in vitro dalam menyerap glukosa perifer (Kumar et al., 2016). Otot diafragma untuk uji in vitro penyerapan glukosa digunakan karena jaringan ini dikenal memiliki reseptor insulin (Wang, 1985).

Hasil analisis menunjukkan bahwa ekstrak daun namnam memiliki kemampuan menstimulasi otot diafragma untuk menyerap glukosa. Kemampuan ini makin tinggi dengan makin tingginya konsentrasi Ekstrak Metanol Daun Namnam (EMDN). Hal ini terlihat dengan jumlah glukosa yang terserap $0.4254 \pm$ $3.23 \mathrm{mg} / \mathrm{mL} / 30$ menit pada konsentrasi 450 $\mathrm{mg} / \mathrm{mL}$ (Tabel 2). Kemampuan EMDN ini lebih tinggi dibandingkan ketika hanya menggunakan insulin. Hal ini terlihat pada persen perubahan penyerapan glukosa ketika hanya insulin $232.18 \%$, namun saat pemberian EMDN $450 \mathrm{mg} / \mathrm{mL}$ naik sebesar $373.72 \%$. Fenomena ini menunjukkan bahwa EMDN pada konsentrasi $450 \mathrm{mg} / \mathrm{mL}$ mampu menstimulasi insulin untuk meningkatkan kemampuannya dalam mendorong glukosa terserap ke dalam sel diafragma. Hasil analisis ini juga menunjukkan adanya nilai penyerapan yang sangat rendah bahkan bernilai negatif (Tabel 2). Menurut Seethanathan et al., (1970) penurunan penyerapan glukosa diafragma pada tikus diduga karena penurunan metabolisme glukosa dalam diafragma atau adanya penghambat penyerapan glukosa, atau keduanya. Namun demikian mekanisme secara pasti dalam kaitannya dengan EMDN perlu ada penelitian lanjutan. Namun demikian penelitian lain terhadap daun $\mathrm{C}$. cauliflora telah menunjukkan adanya potensi sebagai antidiabetes dengan berbagai mekanisme diantaranya kemampuan penghambatan $\alpha$-glukosidase dengan $\mathrm{IC}_{50}$ $5.58 \pm 2.0 \mu \mathrm{g} / \mathrm{mL}$ (Sumarlin et al., 2016), penghambatan $\alpha$-amilase sebesar $72.59 \%$ (Sumarlin et al., 2015b) dan sifat hipoglikemik (Aziz et al., 2017).

Penelitian Somani et al., (2012) juga telah menunjukkan bahwa ekstrak metanol dari daun Couroupita guianensis secara signifikan menghambat aktivitas enzim metabolisme karbohidrat dan meningkatkan 
penggunaan glukosa oleh jaringan perifer. Hal yang sama juga ketika Kumar et al., (2015) menemukan bahwa pemberian ekstrak air $H$. cordata memberikan serapan glukosa pada hemi-diafragma lebih tinggi dibandingkan ketika hanya diberikan insulin saja. Tingginya penyerapan ekstrak tanaman dibandingkan insulin juga telah dikemukakan olen Suthar $e t$ al., (2009) yang melakukan penelitian terhadap ekstrak air panas dari buah Helicteres Isora. Ekstrak Helicteres Isora mampu meningkatkan penyerapan glukosa oleh hemidiafragma tikus terisolasi tetapi kurang efektif dibandingkan insulin. Namun penyerapan setiap tanaman tersebut berbedabeda. Dawoud dan Shayoub (2015) juga telah memperoleh data peningkatan penyerapan glukosa pada hemidiafragma oleh ekstrak etanol Eucalyptus camaladulensis sebesar $116,2 \%$. Kemampuan ini diduga terjadi melalui stimulasi langsung pengambilan glukosa oleh ekstrak etanol Eucalyptus camaladulensis. Mekanisme ini pun dapat pula terjadi pada EMDN sehingga dapat digunakan sebagai agen antihiperglikemik melalui mekanisme peningkatan pengambilan glukosa oleh otot.

Flavonoid diduga memiliki peranan dalam meningkatkan serapan glukosa oleh otot diafragma tersebut. Keberadaan senyawa flavonoid pada EMDN ini terlihat melalui uji kualitatif menggunakan FTIR (Fourier Transform Infrared) dengan menggunakan kuersetin sebagai standar (Tabel 3). Hasil FTIR menunjukkan adanya kemiripan gugus fungsi yang dominan antara ekstrak sampel EMDN dan kuersetin pada beberapa panjang gelombang (Tabel 3). Pada penelitian lain terhadap EMDN menunjukkan bahwa terdapat fenolik dan flavonoid masing-masing 1,0096 $\pm 0.1170 \mathrm{mg}$ GAE$/ \mathrm{g}$ sampel (Gallic Acid Equivalents) dan $0.0962 \pm 0.0049 \mathrm{mg} \mathrm{QE} / \mathrm{g}$ sampel (Equivalents of Quercetin) (Sumarlin

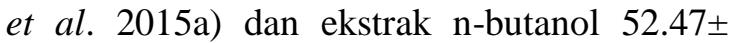
$0.26 \mathrm{mg} \mathrm{GAE} / \mathrm{g}$ sampel dan $4.1392 \pm 0.3245$ $\mathrm{mg}$ QE/g sampel (Sumarlin et al., 2016). Hasil analisis senyawa bioaktif pada tanaman tersebut menunjukkan pula bahwa adanya fenolik dan flavonoid (Aziz dan Iqbal, 2013), prosianidin trimer, prosianidin tetramer, prosianidin heksamer, taksifolin pentosida, katekin, viteksin, isoviteksin, kaempferol heksosida, kuersetin pentosida, kuersetin heksosida, apigenin-6- $C$-glukosida-8- $C$ glukosida, kaempferol-koumaril heksosida dan isorhamnetin heksosida (Ado et al., 2015).

Tabel 2. Kemampuan penyerapan glukosa oleh sel diafragma secara in vitro

\begin{tabular}{llc}
\hline Kel & Medium Inkubasi & $\begin{array}{c}\text { Glukosa terserap } \\
(\mathbf{m g} / \mathbf{m L} / \mathbf{3 0} \text { menit })\end{array}$ \\
\hline I & Larutan tirode (mengandung glukosa) dan akuades sebagai kontrol. & $0.0898 \pm 1.03^{\mathrm{a}}$ \\
II & Larutan tirode (mengandung glukosa) dan Insulin sebagai kontrol positif. & $0.2983 \pm 6.48^{\mathrm{b}}$ \\
III & Larutan tirode (mengandung glukosa) dan EMDN $150 \mathrm{mg} / \mathrm{mL}$ & $-0.3780 \pm 9.32^{\mathrm{c}}$ \\
IV & Larutan tirode (mengandung glukosa) dan EMDN $300 \mathrm{mg} / \mathrm{mL}$ & $0.0488 \pm 4.03^{\mathrm{d}}$ \\
V & Larutan tirode (mengandung glukosa) dan EMDN $450 \mathrm{mg} / \mathrm{mL}$ & $0.4254 \pm 3.23^{\mathrm{e}}$ \\
\hline EMDN = Ekstrak Metanol Daun Namnam. Hasil dituliskan dalam bentuk rata-rata \pm SD dengan $\mathrm{n}=3$ dengan signifikasi $\mathrm{p}$ \\
$<0.05$. a, b, c, d, e dengan superskrip yang berbeda pada kolom yang sama menunjukkan menunjukkan perbedaan secara nyata \\
(P <0.05)
\end{tabular}

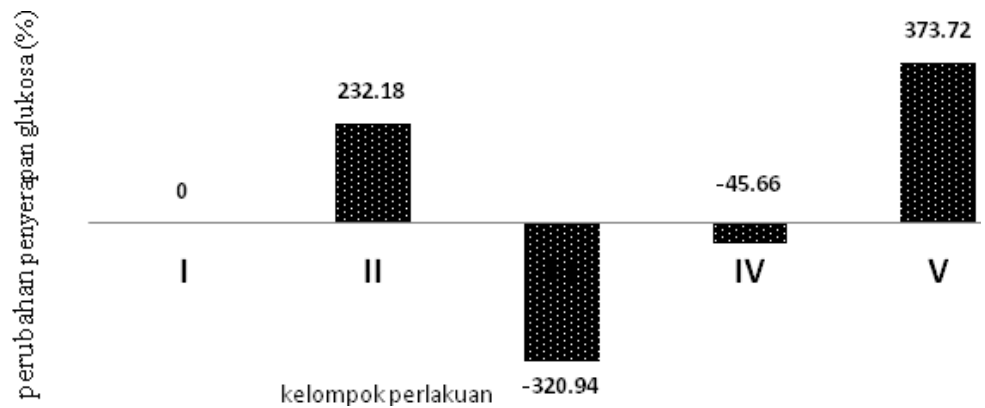

Gambar 2. Grafik persen perubahan penyerapan glukosa oleh EMDN pada otot diafragma 
Tabel 3. Prediksi puncak spektrum FTIR EMDN fraksi cair-cair

\begin{tabular}{clll}
\hline Sampel & \multicolumn{1}{c}{ Bilangan Gelombang $\left(\mathbf{c m}^{-1}\right)$} & Pustaka $\left(\mathbf{c m}^{-1}\right)$ & \multicolumn{1}{c}{ Gugus Fungsi } \\
\hline Ekstrak & 3452.73 & $3680-3650$ & Regangan O-H (terikat) \\
fraksi & 2925.17 & $2850-2960$ & Regangan $\mathrm{CH}_{3^{-}},-\mathrm{CH}_{2^{-}}$ \\
cair-cair & 1717.68 & $1690-1766$ & Regangan C=O \\
& $1614.49 ; 1519.01$ & $1500-1600$ & Regangan C=C aromatik \\
& 1447.64 & $1350-1470$ & Tekukan C-H alifatik \\
& 1125.51 & $1080-1300$ & Regangan C-O \\
& 1006.89 & $990-1060$ & Regangan C-OH siklik \\
& 677.04 & $675-870$ & Tekukan C=C (aromatik tersubtitusi) \\
\hline Kuersetin & 3413.19 & $3680-3650$ & Regangan O-H (terikat) \\
(Standar) & 1666.57 & $1647-1760$ & Regangan C=O \\
& $1610.63 ; 1563.37 ; 1524.79$ & $1500-1675$ & Regangan C=C aromatik \\
& $1265.36 ; 1203.63 ; 1170.84 ; 1133.23 ;$ & $1080-1300$ & Regangan C-O \\
& 1095.61 & & \\
& $1014.60 ; 940.34$ & $990-1060$ & Rengangan C-OH siklik \\
& $869.93 ; 820.75 ; 726.33$ & $675-870$ & Tekukan C=C (aromatik tersubtitusi) \\
\hline
\end{tabular}

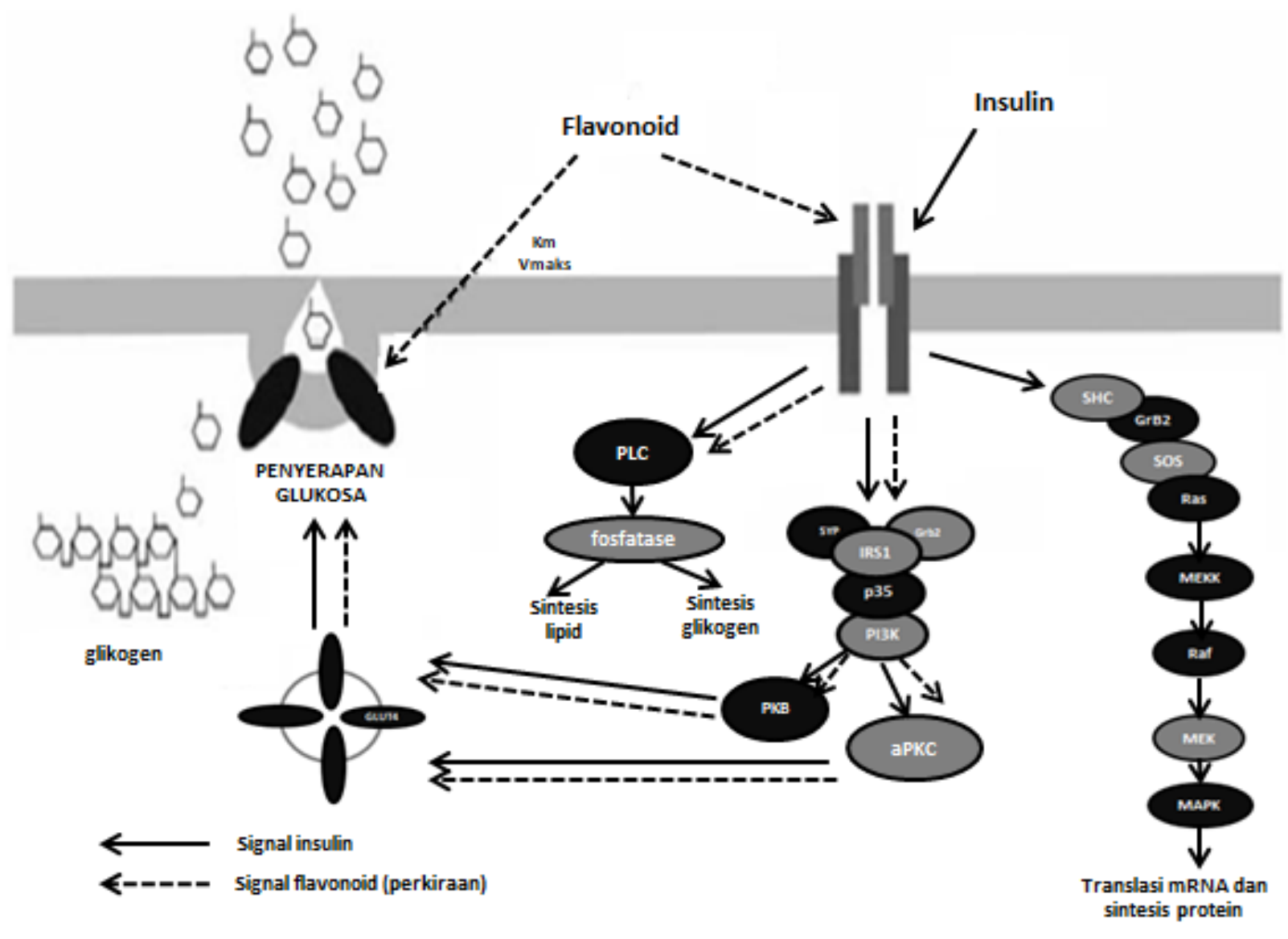

Gambar 3. Model mekanisme kerja flavonoid yang berkaitan dengan penyerapan glukosa. Keterangan : reseptor insulin (IR), protein substrat reseptor insulin (IRS1-4), Cbl dan SHC, Fosforilasi protein IRS, Src Homologi 2 (SH2), molekul adaptor sebagai subunit regulator PI3K, molekul adaptor Grb2, yang berkaitan dengan SOS untuk mengaktifkan jalur Ras-MAPK. Enzim PI3K terdiri dari subunit regulator (p85) dan katalitik (p110) yang mengkatalisis pembentukan second messenger lipid PIP3 dalam sel, suatu aktivator alosterik dari phosphoinositidedependent kinase (PDK). Target dari PDK meliputi isoform PKB/Akt dan tipe protein kinase $\mathrm{C}$ (PKC) Bersama-sama dengan PI3K, mengaktifkan PKB/Akt dan tipikal PKC terlibat dalam stimulasi insulin translokasi GLU4, penyerapan glukosa dan sintesis glikogen (Cazarolli et al., 2008). 
Hal ini diperkuat oleh Jadhav dan Puchchakayala (2012) yang menemukan adanya peningkatan serapan glukosa pada sampel flavonoid seperti kuersetin. Penelitian lain juga oleh Kumar et al., (2016) menyatakan bahwa kuersetin (flavonoid) dapat meningkatkan serapan glukosa sebesar $4.88 \%$ dibandingkan insulin. Menurut Kumar et al., (2016) mekanisme yang mungkin terjadi oleh flavonoid sebagai agen antidiabetik adalah 1) aktivitas penghambatan transport glukosa, 2) penentuan penyerapan glukosa oleh hemidiafragma tikus terisolasi.

Mekanisme ini dipertegas oleh Cazarolli et al., (2009) yang menunjukkan adanya pengaruh keberadaan apigenin-6-C(2"-O- $\alpha$-L-ramnopiranosil)- $\beta$-1-fukopiranosida yang diisolasi dari daun Averrhoa carambola L. (Oxalidaceae). Bahkan Cazarolli et al., (2008) telah menggambarkan mekanisme kerja flavonoid dalam meningkatkan kemampuan insulin dalam penyerapan glukosa oleh otot (Gambar 3). Zygmunt et al., (2010) telah memberikan penjelasan bahwa Naringenin (Flavonoid) meningkatkan penyerapan glukosa dari sel otot rangka melalui mekanisme yang berhubungan dengan AMPK-dependent. Dengan demikian EMDN memiliki potensi sebagai agen antidiabetes melalui mekanisme peningkatan penyerapan glukosa oleh otot.

\section{SIMPULAN}

Terjadi peningkatan penyerapan glukosa oleh diafragma ketika konsentrasi ekstrak daun namnam (C. cauliflora) meningkat dan tertinggi pada konsentrasi $450 \mathrm{mg} / \mathrm{mL}$ dengan serapan $0.4254 \pm 3.23$ $\mathrm{mg} / \mathrm{mL} / 30$ menit dengan peningkatan sebesar $373.72 \%$ dibandingkan kontrol air. Diduga kemampuan ekstrak tanaman C. Cauliflora menyerap glukosa disebabkan keberadaan golongan flavonoid. Hal ini menunjukkan bahwa daun tanaman namnam (C. cauliflora) memiliki potensi sebagai obat antidibetes DMT2 melalui mekanisme peningkatan penyerapan glukosa ke dalam sel.

\section{UCAPAN TERIMA KASIH}

Ucapan terimakasih kepada Lembaga Penelitian dan Pengabdian Masyarakat melalui
Pusat penelitian UIN Syarif Hidayatullah Jakarta dengan bantuan dana riset tahun 2016. Terimakasih pula kepada Hilyatuz Zahroh, M.Pkim, M.Si karena telah melakukan pengeditan terhadap beberapa bagian dari artikel ini.

\section{DAFTAR PUSTAKA}

Ado MA, Abas F, Ismail IS, Ghazali HM, Shaari K. 2015. Chemical profile and antiacetylcholinesterase, antityrosinase, antioxidant and $\alpha$-Glucosidase inhibitory activity of Cynometra cauliflora $L$. leaves. J Sci Food Agric. 95(3):635-642.

Aziz A, Iqbal M. 2013. Antioxidant activity and phytochemical composition of Cynometra cauliflora. J Exp Integr Med. 3(4):337341.

Aziz, AFA, Bhuiyan SA, Iqbal M. 2017. An Evaluation of antioxidant and antidiabetic potential of Cynometra cauliflora (Namnam, Fabaceae). Transac on Sci and Tech. 4(3-3):372 - 383

Cazarolli LH, Folador P, Moresco HH, Brighente IMC, Pizzolatti MG, Silva FRMB. 2009. Mechanism of action of the stimulatory effect of apigenin-6-C-(2"-O-alpha-1rhamnopyranosyl)-beta-1-fucopyranoside on (14)C-glucose uptake. Chem-Biol Interact. 179:407-12.

Cazarolli LH, Zanatta L, Alberton EH, Figueiredo MS, Folador P, Damazio RG, Pizzolatti MG, Silva FR. 2008. Flavonoids: cellular and molecular mechanism of action in glucose homeostasis. Mini Rev Med Chem. 8(10): 1032-8.

Dawoud ADH, Shayoub MH. 2015. In vitro study of Aqueous and Ethanolic Extracts of Eucalyptus camaladulensis on glucose uptake by isolated rat hemi-diaphragm. $J$ Comp Tech. 4(3):2278 - 3814

IDF Diabetes Atlas. 2015. International Diabetes Federation. Annual Report 2015. International Diabetes Federation.

Jadhav R, Puchchakayala G. 2012. Hypoglycemic and antidiabetic activity of flavonoids: Boswellic acid, ellagic acid, quercetin, rutin on Streptozotocin-Nicotinamide induced type 2 diabetic rats.Int $J$ Pharm Pharmac Sci. 4(2):251-256. 
Jung M, Park M, Lee HC, Kang YH, Kang ES, Kim SK. 2006. Anti-diabetic agents from medicinal plants. Curr Med Chem. 13(10):1203-1218.

Kumar M, Prasad SK, Hemalatha S. 2016. In vitro study on glucose utilization capacity of bioactive fractions of houttuynia cordata in isolated rat hemidiaphragm and its major phytoconstituent. Adv Pharmacol Sci. 2016:1-5.

Riset Kesehatan Dasar (Riskesdas). 2013. Badan Penelitian dan Pengembangan Kesehatan Kementerian RI tahun 2013. Diakses: 19 Oktober 2014 darihttp://www.depkes.go.id/resources/dow nload/general/Hasil\%20Riskesdas\%202013. pdf.

Sabu MC, Subburaju T. 2002. Effect of Cassia auriculata Linn. on serum glucose level, glucose utilization by isolated rat hemidiaphragm. J Ethnopharm. 80:203-206.

Shaw JE, Sicree, RA, Zimmet, PZ. 2010. Global estimates of the prevalence of diabetes for 2010 and 2030. Diab Res Clini Pract. 87(1):4-14.

Somani G, Chaudhari R, Sancheti J, Sathaye S. 2012. Inhibition of carbohydrate hydrolysing enzymes by methanolic extract of couroupita guianensis leaves. Int $J$ Pharm Bio Sci. 3(4):511 - 520.

Sumarlin L, Suprayogi A, Rahminiwati M, Satyaningtijas A, Sukandar D, Pangestika, H. 2016. Ability of leaf extract namnam (Cynometra cauliflora) as antidiabetic agents $\alpha$-glucosidase inhibition through at some stage extraction.Int J Sci: Basic and Appl. Res. 30(2):112-123.

Sumarlin L, Suprayogi A, Rahminiwati M, Tjachja A, Sukandar D. 2015a. Bioactivity of methanol extract of namnam leaves in combination with trigona honey. J Teknol dan Industri Pangan. 26(2):144-154.

Sumarlin, LO, Suprayogi A, Rahminiwati M, Satyaningtijas A, Sukandar D, Tjachja A, Amalia I. 2015b. Antidiabetic And Antidiarrheal Activity From Extract Ofnamnam (Cynometra Cauliflora) Leaf. International Conference on Global Resource Conservation (ICGRC)

Seethanathan P, Vijayagopalan P, Augusti KT, Kurup PA. 1970. Glucose uptake by the diaphragm in rats fed normal and hypercholesterolaemic diets and the effect of insulin on uptake. Atherosclerosis. 11(2): 343-347.doi:

Suthar M, Rathore GS, PareekA. 2009. Antioxidant and antidiabetic activity of Helicteres isora (L.) Fruits. Indian J Pharm Sci.71 (6): 695-699.

Wang C. 1985. Insulin-stimulated glucose uptake in rat diaphragm during postnatal development: Lack of correlation with the number of insulin receptors and of intracellular glucose transporters. Proc Natl Acad Sci. 82:3621-3625.

Zygmunt K, Faubert B, MacNeil J, Tsiani E. Naringenin. 2010. A citrus flavonoid, increases muscle cell glucose uptake via AMPK. Biochem Biophys Res Commun. 398(2):178-183. 